\title{
INTEGRATION OF IRRIGATED LUCERNE WITH INTENSIVE CROPPING
}

\author{
C. G. JANSON \\ Winchmore Irrigation Research Station, Ministry of \\ Agriculture and Fisheries, Ashburton
}

Abstract

Irrigation on light land has stimulated both an expansion and an intensification of cash cropping programmes on this country which, together, have increased winter carrying capacities and reduced spring/summer grazing areas. This has created a need for a spring/ summer grazing system capable of supporting a high concentration of stock. It is suggested that irrigated lucerne can form the foundation for such a system and results are given of preliminary testing of the concept with ewes and lambs.

\section{INTRODUCTION AND DEVELOPMENT OF THE CONCEPT}

ThE Introduction of irrigation to light land properties introduces opportunities for radical changes to the farming systems traditionally operated on these areas. Immediately obvious changes tend to generate a succession of opportunities for further change until completely new systems are born. The concept outlined in this paper of using, irrigated lucerne as the stock-carrying, fertilitybuilding partner to a cash cropping programme is perhaps one of the last stages in such a succession of events.

Irrigation has greatly increased the potential for cash cropping on the light stony soils and many farmers have been quick to realize this. However, in accepting the challenge and grasping all the opportunities irrigation presents along the way, a situation has developed in which a re-assessment is now needed of the "grazed pasture" phase of their rotations.

This is primarily due to two things. First, the farmer finds that with reasonable water supplies he can now sow the whole of his crop area in the spring rather than being forced to sow all the wheat and the pea area, for instance, in the winter to prevent drought seriously curtailing their yield. This ability to spring-sow rather than winter-sow crops means that the whole of the area currently in the cropping phase of the rotation is now available for grazing throughout the winter. Accordingly, a balance of autumn-sown greenfeeds and forages can be used on the area which will provide feed through to the spring. If these are used in conjunction with straws (by-products of the arable system) 
and the rest of the farm (i.e., the area nof currently in the cropping phase of the rotation), it is clear the system has a higher stock carrying capacity over the winter period than previously.

Secondly, this insertion of winter greenfeeds between the annual cash crops, plus the dramatic improvement in the vigour and yield of the pasture area with irrigation, has allowed a marked expansion of cropping on the light soils. Consequently, there are now farmers on these soils annually sowing 50\% and more of their properties into cash crops in the spring.

It is this drastic reduction to the grazing area that occurs in the spring with cropping programmes of this intensity, plus the higher winter carrying capacity associated with spring sowing programmes, which has produced a situation demanding either partial destocking in spring or the development of a spring/summer grazing system capable of a very high carrying capacity.

This paper is concerned with the second alternative. The suggestion is advanced that rotationally grazed irrigated lucerne can provide the foundation for such a system for the following reasons:

(1) Irrigated lucerne has a considerably higher growth rate over the warm summer months than irrigated grass/clover pastures. At Winchmore, Wairau lucerne cut at seven-week intervals and irrigated at $75 \%$ available soil moisture depletion (A.S.M.D.), had a mean growth rate of $90 \mathrm{~kg} \mathrm{DM} / \mathrm{ha} /$ day over the December/January/February period, while a perennial ryegrass/white clover pasture cut at four-weekly intervals and irrigated on the same soil moisture basis as the lucerne had a mean growth rate over the same period of $51 \mathrm{~kg} \mathrm{DM} /$ ha/day (pasture figures: D. S. Rickard, pers. comm.).

(2) The high quality of the apices and uppermost leaves of actively growing lucerne enables lambs to be successfully weaned on to it at a very young age (Jagusch et al., 1970; Jagusch and McConnell, 1971). Because of this, the period of very heavy feed demand associated with the lactating ewe Can be markedly shortened relative to that possible with conventional pasture.

(3) The proven ability to establish lucerne. successfully on these light soils under a wide range of spring-sown irrigated cash crops (Janson and Knight, 1973) means the production lag traditionally associated with first-year lucerne can be eliminated from the system. 
(4) The peak irrigation demand of lucerne which comes after mid-December is complementary to the peak irrigation demand of the cropping area which comes before midDecember.

\section{PRELIMINARY TESTING OF THE CONCEPT}

A vigorous, surface-irrigated stand of Wairau lucerne was subdivided into six small paddocks and on September 24 stocked with $55 \mathrm{~kg}$ Romney ewes at a rate of $40 /$ ha with $110 \%$ of two- to four-day-old lambs at foot. At this time the lucerne was 18 to $20 \mathrm{~cm}$ high and had accumulated $1950 \mathrm{~kg} / \mathrm{ha}$ DM. Rotational grazing was adopted and irrigation was applied on a $75 \%$ A.S.M.D. basis.

On October 26, at the end of the first rotation and $4 \frac{1}{2}$ weeks after grazing commenced on the unit, the lambs were weaned back on to the new growth of the first paddock while the ewes remained behind to clean up the stalks on the last paddock. This system was adhered to for the rest of the spring and summer. The lambs preceded the ewes into each paddock to top and leafstrip the lucerne, while the ewes followed on, cleaning up the stalks and any rejected, fouled or trampled herbage. No additional feed was supplied to the ewes.

On December 24, lambs $28 \mathrm{~kg}$ or over were removed from the unit. Thirty percent had attained the required weight by this date and at a second weighing on January 7 a further $32 \%$ were removed. Accordingly, because of the vigorous condition and the excellent supply of the lucerne on the unit at this date, plus the satisfactory condition of the "follower" ewes, a mob of "store" lambs (average liveweight $21 \mathrm{~kg}$ ), equal in number to that of the original Iambs placed on the unit with their mothers, were added to the unit to be fattened along with the remainder of the original lambs.

By March 26, all the original and all the bought-in store lambs had been removed from the unit after reaching the $28 \mathrm{~kg}$ drafting weight. Six irrigations had been applied and $720 \mathrm{~kg} / \mathrm{ha}$ lucerne DM remained on the unit.

Consequently, over the six-month period from September 24 to March 26, the lucerne unit operating under this early weaning, rotational grazing system had supported 40 ewes/ha, had fattened from birth 44 lambs/ha and had fattened from "store" condition a further 44 lambs/ha. 


\section{DISCUSSION AND CONCLUSIONS}

These results were achieved at the expense of a substantial ewe weight loss over the last $2 \frac{1}{2}$ months of the trial. However, this is of little consequence, since in this study the full complement of ewes were carried through to March 26 when, in practice, all the culls would be removed from the system after weaning. The proportion removed as culls could vary from as little as $20 \%$ under a replacement policy based on bought-in two-tooths, to over $50 \%$ under a 2 -year-ewe policy.

This trial has indicated that irrigated lucerne has the ability to support a high concentration 'of stock under a ewe and fat lamb system over the spring, summer and early autumn period if the stock are rotationally grazed and if the lambs are weaned very early. This indication, in conjunction with its complementary irrigation requirements to cash cropping, and its ability to establish under most spring crops and to improve soil nitrogen levels, suggest that lucerne could have an important role to play in the future of mixed arable farming under irrigation.

\section{REFERENCES}

Jagusch, K. T.; Clark, V. R.; Jay, N. P., 1970. N.Z. $l l$ agric. Res., 13: 808-14.

Jagusch, K. T.; McConnell, G. R., 1971. Proc. Lincoln Coll. Fmrs' Conf.: 73-8.

Janson, C. G.; Knight, T. L., 1973. N.Z. $/ l$ exp. A gric., 1: 243-51. 